\title{
Videodança "Procedimentos para o Fim Do Mundo": uma dramaturgia de si em vídeo
}

\section{Screendance "procedures for the end of the world": a dramaturgy of yourself in vídeo}

\author{
Davidson José Martins Xavier \\ Universidade Federal de Goiás - UFG, Goiânia/GO, Brasil \\ E-mail: navicularse@gmail.com
}

\section{Resumo}

Este estudo tem como objetivo a compreensão da autobiografia presente nas obras de videodança Suspender, Todos os caminhos, Delírio e Gênius, resultado de um processo de investigação em videodança denominado websérie "Procedimentos para o fim do mundo", criado pelo bailarino Davidson Xavier. A partir de análises das cenas criadas para o vídeo e releitura de diário de bordo, o texto busca refletir de forma fenomenológica sobre a videodança, a noção de "corpocasa", dramaturgia e a pandemia de SARS-CoV 2, no ano de 2020.

\section{Palavras-chave}

Autobiografia. Dramaturgia. Videodança. Corpocasa. Fenomenologia. Processo de Criação.

\section{Keywords}

Autobiography. Dramaturgy. Screen Dance. Body-house. Phenomenology. Creation Process. 


\section{Portas fechadas}

Desde o primeiro caso do novo Coronavírus ser identificado em Wuhan, na China, em dezembro de 2019, o mundo entrou em alerta devido à alta transmissão do vírus que ganhou o nome de SARSCoV 2. Em março de 2020, a Organização Mundial de Saúde (OMS) definiu o surto como pandemia, assim a sociedade precisou se reinventar. Não seria diferente no universo artístico: galerias, museus, teatros, casas de shows fechados. Essa nova realidade abriu espaço para pesquisas cunhadas na virtualidade dos corpos, nos quais trabalhos artísticos feitos para a exibição em formato on-line ganharam caráter síncrono ou assíncrono.

Vários mecanismos de incentivo, inclusive criados pelo próprio Governo Federal por meio da Lei Aldir Blanc (Decreto 10.489/20), incentivaram artistas a continuar processos criativos em casa. Dentre estes mecanismos de fomento o Projeto Inspirarte ${ }^{1}$, selecionou 45 propostas artísticas para execução durante este período, e abriu seleção para artistas da região, estudantes e servidores do Instituto $\mathrm{Fe}$ deral no Estado de Goiás.

O texto aqui apresentado é um relato artístico em primeira pessoa que visa refletir sobre o projeto Procedimentos para o fim do mundo (PFM) ${ }^{2}$, que foi aprovado neste edital e realizado no ano de 2020 , na cidade de Aparecida de Goiânia, sendo idealizado e interpretado por mim, autor deste relato. Em

\footnotetext{
1 Neste período a Reitoria do Instituto Federal de Educação e Ciência e Tecnologia de Goiás, por meio da Pró-reitoria de Extensão, publicou no dia 17/06/2020 a abertura de processo para apoio financeiro institucional a Ações Artísticas e Culturais produzidas durante o período de isolamento social para disponibilização em plataformas digitais. $O$ projeto apoiou o desenvolvimento e veiculação digital de ações artísticas ampliando a atuação do IFG/GO na promoção do desenvolvimento humano e social, tentando amenizar os efeitos causados pelas medidas de contingenciamento provocadas pela pandemia da COVID-19.
}

2 Usarei a sigla PFM para me referir a estas videodanças, este trabalho Procedimentos para o fim do mundo é uma Web-série para plataformas digitais e atualmente está hospedada em meu canal do Youtube: https://tinyurl.com/mx2svsv4. O trabalho possui quatro episódios que podem ser assistidos individualmente. Até o momento os videodanças participaram dos festivais: Midiadança - Mostra Universitária Iberoamericana de videodança. Midiadança - do Instituto de Cultura e Arte, da Universidade Federal do Ceará (ICA/UFC) com os capitulos 1 - Suspender e 2 - Todos os caminhos. Fuga 13 - XIII Festival Universitário de Artes Cênicas de Goiás (UFG/EMAC) com o Capítulo 1 Suspender. Congresso Forma - Congresso Piauiense de Ações Formativas, Performativas e Afirmativas em Dança (UESPI), com o Capítulo 4 - Gênius. um trabalho que se propõe a refletir sobre os espaços vazios e solitários que encontramos durante a pandemia, utilizar em vídeo uma casa repleta de folhas secas, vazia e trancada, faz-me perceber que a casa mostrada em vídeo, seria o reflexo do próprio personagem/artista. Este trabalho, refletindo sobre o processo criativo e resultado em vídeo, tem por direcionador a concepção de Bachelard (2000) e questiona-se: até que ponto o espaço é compositor de devaneios artísticos junto com o artista?

\section{Casa escancarada - abertura para o novo}

Devido às portas fechadas e o isolamento social, a websérie PFM pretendeu lançar olhar sobre a solidão na qual todo ser humano está sujeito. Os artistas envolvidos no processo; Bernardo Morais (Direção de fotografia), Arthur Araujo (Trilha sonora), Jhey Matos (figurino) e eu (intérprete-criador), iniciaram os processos de pesquisa com o intuito de criar quatro novos videodanças em agosto de 2020 .

A minha motivação inicial era aplicar, na prática de videodança, conceitos de performance $a^{3}{ }^{3}$, dança-teatro ${ }^{4}$ e autobiografia ${ }^{5}$. Esta motivação, ganhou

3 No ano de 2020, como professor Substituto na Universidade Federal de Goiás (UFG), ministrei uma disciplina de Núcleo Livre chamada "Corpo performático: dispositivos para criação". Esta disciplina pretendia ser um espaço de estudo e prática dos princípios e elementos da arte da performance. Neste lugar de construção de novas visualidades do corpo por meio de dispositivos audiovisuais pude repensar minha própria criação, onde questões corporais interferiram em meu trabalho enquanto intérprete.

4 Atualmente possuo um projeto de pesquisa Dramaturgia à Deriva; Possibilidades de abordar o corpo pela dança-teatro, orientado pela professora Dra. Natássia Duarte Garcia Leite de Oliveira e co-orientado pela Professora Dra. Maria Angela Ambrosis, está integrado à linha de pesquisa 'Estéticas e Poéticas das Artes da Cena', pelo Programa de Pós-Graduação em Artes da Cena (PPGAC), da Escola de Música e Artes Cênicas (EMAC), pela Universidade Federal de Goiás (UFG).

5 Faço parte do Núcleo de Práticas Artísticas Autobiográficas (NuPAA) que é um grupo de pesquisa da Faculdade de Artes Visuais (FAV/UFG). Na época deste trabalho audiovisual, desenvolvia a pesquisa "Corpo bordado: Por uma dramaturgia do corpo, na Linha de pesquisa Processos Artísticos do Corpo e da Intimidade, sobre orientação do prof Dr. Odinaldo da Costa Silva, que finalizou em setembro de 2021. Em edital para o ano de 2021/2022, estou com outro projeto, cujo título é "Mito-guia Catrumano: De quatro patas no sertão Geraizeiro". 
características de autoficção ${ }^{6}$, quando o desejo de mostrar o confinamento pelo viés da solidão me fez identificar uma dança ínfima, que se relacionou com o espaço minha casa, e nasceu ligada a gestos minimalistas e cotidianos.

Bachelard aponta que a casa é um espaço de abrigo que leva o indivíduo ao devaneio. Observando isso, durante a execução do trabalho percebi que o espaço influenciava uma narrativa e esboçava uma dramaturgia. Este modo de vir a ser no mundo, aparece tanto na movimentação do intérprete, quanto a angulação de câmera.

Segundo Bachelard (2000) no livro Poética do espaço, a casa é um lugar de proteção do sonhador, um lugar que se sustenta por seus valores e que preserva as experiências que marcam a vida dos seres. Deste modo, posso compreender que o personagem posto em vídeo, este personagem pixelado expõe um modo do próprio indivíduo ser no mundo a medida que expõe sua relação com os objetos e o entorno.

Para os fenomenólogos como Bachelard, que seguiram o pensamento de Edmund Husserl, é necessário estudar os fenômenos, ou seja, a própria coisa que nos é dada, o modo como é percebida, como pensa e como fala. Caminhando por este lugar é necessário ter uma inocência infantil, que não forja hipóteses, mas sim experiencia os laços de compreensão das coisas.

A noção de corpocasa - casa física de tijolos como uma analogia a casa psíquica - ficou presente nas pesquisas e durante o processo chamou-me atenção os cantos empoeirados, as teias de aranha, os pequenos cantos escuros da casa onde moro. Segundo Bachelard (2000), a casa é lugar em que afetos do cotidiano se mostram, criando assim um "canto do mundo", um espaço onde se é permitido habitar com segurança e intimidade, diferente de outras partes do mundo.

A casa adquire as energias físicas e morais

6 O termo foi cunhado por Serge Doubrovsky, em 1977. Porém continua nebuloso por ter uma linha muito tênue com autobiografia. Alguns autores (Philippe Lejeune,1971) comunicam que o termo é um invasor de campo e outros (Jovita Noronha, 2014) notam que o termo é usado na literatura para fidelizar uma produção autobiográfica, porém disfarçada de literatura ficcional. Eu utilizo o termo por sentir que meu trabalho com mitologias próprias se beneficia do termo criando um espaço de fronteira. de um corpo humano. Ela curva as costas sob o aguaceiro, retesa os rins. Sob as rajadas, dobra-se quando é preciso dobrar-se, segura de poder endireitar-se de novo no momento certo, desmentindo sempre as derrotas passageiras. Tal casa convida o homem a um heroísmo cósmico. É um instrumento para afrontar o cosmos. As metafísicas "do homem atirado no mundo" poderiam meditar concretamente sobre a casa atirada na borrasca, desafiando a cólera do céu. Contra tudo e contra todos, a casa nos ajuda a dizer: serei um habitante do mundo, apesar do mundo (BACHELARD, 2000, p. 62).

Isolado em casa - ainda estou ao redigir este texto - a noção de intimidade me fez perceber meIhor este espaço. Na passagem citada acima, Bachelard mostra que o próprio corpo é uma espécie de casa e me fez refletir sobre a noção de corpocasa: um lugar que se move, dobrando-se e endireitando-se. Estaria a casa dançando? Os cantos mal percebidos da casa física, também refletiram os meus cantos pouco observados e por este motivo, durante o feitio de PFM, entendi que estes cantos deveriam ser também abismos onde meus gritos deveriam ecoar. "A imagem da casa se torna a topografia do nosso ser íntimo" (BACHELARD, 2000, p. 14) que cartografa desejos de um corpo encarcerado buscando formas novas de se expressar.

Com efeito, a casa é, à primeira vista, um objeto rigidamente geométrico. Somos tentados a analisá-la racionalmente. Sua realidade inicial é visível e tangível. É feita de sólidos bem talhados, de vigas bem encaixadas. A linha reta predomina. $O$ fio de prumo deixou-Ihe a marca de sua sabedoria, de seu equilíbrio. Tal objeto geométrico deveria resistir a metáforas que acolhem o corpo humano, a alma humana. Mas a transposição para o humano ocorre de imediato, assim que encaramos a casa como um espaço de conforto e intimidade, como um espaço que deve condensar e defender a intimidade. Abre-se então, fora de toda racionalidade, o campo do onirismo (BACHELARD, 2000,p. 64).

Esta estabilidade da casa tensiona o corpo em movimento, expressando dúvidas e devaneios que qualquer corpo enfrenta. Estas tensões geraram em meus cadernos de artista reflexões sobre o habitar-se e o desprender-se do corpo. Deste modo, escrevi partes do processo de criação em um caderno usado para escrituras, desenhos, roteiros e per- 
guntas que pudessem surgir. Em um dos escritos, surgem algumas palavras soltas, como: "Ter casa / ser casa / Ler casa / (cerca) asa / cercar as asas / Empoleirar-se nas viscosidades do corpo" (trecho de diário de artista).

Estas reflexões poéticas, que são registros, se tornam também uma orientação e reflexão sobre a arte do movimento individual, relacionam espaços, corpo e movimentos autorais tornando estes elementos coautores juntamente com os participantes do processo.

Para Bachelard, o espaço é "como um instrumento de análise para a alma humana" (2000, p. 20), é por meio do espaço se pode chegar a uma fenomenologia da imaginação. $\mathrm{O}$ autor buscava uma forma de conhecer a imagem em sua origem, carregada de pureza, por meio destas imagens, chega-se a pureza da alma humana. O autor trata que a casa é um lugar de proteção do sonhador, um lugar que se sustenta por seus valores e que preserva as experiências que marcam a vida dos seres. Deste modo, posso compreender que o personagem posto em vídeo, este personagem pixelado expõe um modo do próprio indivíduo ser no mundo por sua relação com os objetos e o próprio entorno.

\section{Então, os lugares onde se viveu o devaneio reconstituem-se por si mesmos num novo devaneio [...] a casa é uma das maiores (for- ças) de integração para os pensamentos, as lembranças e os sonhos do homem. Nessa integração, o princípio de ligação é o deva- neio. O passado, o presente e o futuro dão à casa dinamismos diferentes, dinamismos que não raro interferem, às vezes se opon- do, às vezes excitando-se mutuamente (BA- CHELARD, 2000, p. 26).}

O conceito de PFM nasceu de leituras e reflexões, onde relacionei estudos teóricos de conceitos teatrais, corporais e de performance. O ponto de partida para estas reflexões teóricas, além de Bachelard, foram livros de Renato Cohen (1998) e Lícia Sanchéz (2010), que permearam todo o processo de criação, aliado a esta referência noção do dança-teatro, onde o plano das emoções são mais importantes que o plano das formas que criou um zeitgeist (espírito de uma época) pandêmico, deixando as concepções sobre dramaturgia do corpo em um campo movediço e de deriva, nos quais não necessariamente é importante a definição de um conceito, mas sim uma construção de sentido.
Luciana Lyra (2005) aponta que os mitos sempre estão presentes em processos criativos, desde culturas tradicionais à propostas cênicas de vanguarda, segundo a autora:

A imaginação é sustentáculo para a atuação dos artistas destas comunidades e culturas, configurando-se meio por onde se produz a combinação harmônica entre sons/frases e imagens e de onde são impulsionadas as danças dramatizadas, no afastamento de demônios e medos antepassados, na busca de compreensão de situações da existência (LYRA, 2005, p. 117).

Este ser "automitológico" que existe em vídeo, num espaço fora do tempo que dá força a um ser autobiográfico formado por momentos de fragilidade, reinstaurando-se um ser primordial atemporal.

Por este caminho desenvolvi uma prática artística, e assim surgiu o trabalho em vídeo do "PFM - Ação 1 - O que lembro, tenho" . Após este vídeo, criei outro trabalho denominado "Ação II - Crescer pra passarinho", já com a participação do músico Arthur Araújo na composição de uma trilha sonora autoral.

\section{Criando uma dramaturgia de si}

Atualmente, principalmente nas artes, notase vários trabalhos em que "narrativas vivenciais" (KLINGER, 2008, p. 11) ganham notoriedade. Para além da notoriedade, muitos artistas contemporâneos fazem de sua personalidade e de sua história um objeto de estudo. Segundo Guerreiro "para lá de nos colocar perante algo que nos interpela, porque nos faz pensar nas nossas próprias vidas, [estes trabalhos] demonstra-nos o caráter processual das práticas artísticas contemporâneas" (GUERREIRO, 2011, p. 136).

PFM pretende, por meio de registros audiovisuais, produzir uma dilatação do tempo real escolhendo múltiplas narrativas, ampliando espaços e pontos de vista. Durante o processo de criação, idealizei que os vídeos poderiam ser vistos em separado, isoladamente ou na ordem que se preferir, criando uma dramaturgia no/do encontro. Assim, os trabalhos de

\footnotetext{
7 Link para acesso ao video: https://youtu.be/sBuU7JZogM0. Este trabalho participou do Festival Videodança em casa - mostra online em tempos de Quarentena $-1^{\circ}$ mostra temática online com o tema pés e mãos. Este festival teve curadoria do Dança em foco, IMARP e videodança+.
} 
videodança encontraram na imagem em movimento uma extensão do meu corpo e da minha mente.

Usei tanto a autobiografia quanto a autoetnografia para refletir sobre o trabalho em todas as suas partes, ganhando desta forma, um olhar plural. Assim, pude falar de uma dramaturgia expandida, com outras possibilidades de entendimento, e que se oriente em outros questionamentos que não somente um texto dramático.

Cria-se assim uma dramaturgia do corpo-lugarvídeo que é amplificada e totalmente diferente dos preceitos aristotélicos. Atualmente o termo dramaturgia é bem mais amplo e é utilizado para designar outros pontos que estão intimamente ligados ao fazer cênico. Autores como Ana Pais (2010) expõem o termo dramaturgia expandida quando expressam como o campo dramatúrgico contaminou espaços fora das artes cênicas. A autora relaciona a dramaturgia à uma construção coletiva, como resultado de um conjunto de elementos que são escolhidos durante o processo de criação do espetáculo. Pensando desta forma, o modelo dramatúrgico passa a se intensificar, e ganha vias processuais estudando universos menos palpáveis, desejando lançar âncoras em areias movediças.

O conceito de deriva, aqui, expressa não apenas seu significado original - desgoverno de uma embarcação ao vento -, mas também no sentido de "andar sem rumo". Na teoria da deriva de autoria de Guy Debord (1958) o autor defende que é possível criar um mapa mental de uma determinada cidade enquanto se anda pelas suas ruas (cada ser cria um mapa único). Neste sentido, a deriva se alia a uma experiência cartográfica que aprofunda o olhar sobre o objeto, tendo certeza que não há um método pronto para se aplicar determinada pesquisa. Estar à deriva é servir-se enquanto caminha, é ser modificado pelo caminhar.

A experiência de construir uma dramaturgia à deriva em um processo criativo necessita de bússolas. No meu caso, criei um estudo dramatúrgico baseado em storyboards ${ }^{8}$ que solidificaram os caminhos escolhidos para uma melhor compreensão de PFM. Criando células corporais que se adequavam ao espaço da casa e, posteriormente, fazendo ano-

\footnotetext{
8 Storyboard - procedimento diverso da maioria das encenações que parte de texto/autoria/mapa de personagem para depois divergir na encenação. Parte do pensamento que o texto teatral é fechado, enquanto o storyboard é uma obra em processo, enquanto cria um roteiro com as escolhas ou possibilidades para a encenação.
}

tações do processo, trouxe para o trabalho criativo o lugar do deslimite. Como expresso aqui em parte do diário de artista:

FRASES PARA DANÇAR

$A$ vida tem a tendência de se manchar

Algo que é leve e se adensa

Ir embora é ficar com você mesmo

Nem o próprio poema sabe o que ele guarda

(Tentativas para guardar o céu)

O voo como existência / Dança é deslimite.

O tesouro da vida é o deslumbramento

Quero morrer sentindo. (trecho de diário de artista, s/n)

O diário de artista é uma das tantas facetas da própria obra, ele cria o universo do artista e deixa o terreno da minha criação um lugar fértil, apto a desenvolver uma dramaturgia de si. Bonfitto (2011) contribui a minha reflexão propondo a construção de uma nova dramaturgia:

Sendo assim, a noção de dramaturgia como textura, ao admitir um entrelaçamento de camadas produtoras de sentido, não abriria a possibilidade de reconhecimento de uma dramaturgia desvinculada da representação e da ficcionalização? Em sintonia com as tendências dramatúrgicas gerais da performance apontadas por Fabião, a dramaturgia como textura se dá nesse caso através da articulação não de fatos e ações que remetem a histórias e tramas, mas de qualidades expressivas, de estados, de forças e fluxos que intensificam o acontecimento em processo, gerado pelo contato direto entre performer e público: uma dramaturgia do inefável (BONFITTO, 2011, p. 61).

Refletindo sobre o texto de Bonfitto, percebo que as possibilidades dramatúrgicas não se restringem às limitações do texto, mas têm olhares em fontes desejantes (inefável, deslimite, deriva, devaneio) e em um universo de potência que está mais ligado a conceitos corporais e expressivos, do que a somente processos de escrita.

Este outro olhar sobre o corpo em movimento cria, uma "tessitura de ações podendo ou não incluir a palavra" (BARBA, 1995, p. 69) se relacionando com um vocabulário de cada artista, com caminhos que tem afinidade, com modos ou modelos próprios de se posicionar e seu jeito de utilizar o corpo. Por isso, uma dramaturgia que deriva é amparada pelos 
horizontes do corpo, expandida pela ideia de arte não limítrofe, mostrando que o mover-se tem ligações fortes com a história pessoal e com relações sociais deste corpo frente à percepção do mundo.

Este alargamento do conceito de texto dramático - que nas últimas décadas do século $X X$ trouxe luz, a processos artísticos que não utilizam propriamente um texto teatral - leva artistas como eu a discutirem, compreenderem e corporificarem conceitos em processos de criação e composição cênica à fim de construir outros sentidos, narrativas diferenciadas e etnografias baseadas na própria história.

PFM reflete uma dança autobiográfica, pois acredita que toda dança é uma busca, uma narração de si através do movimento e, nestes quatro trabalhos de vídeo, posso perceber na utilização da minha própria casa, do meu corpo, dos meus movimentos para a criação artística, elementos que fazem parte de matrizes de criação. Estas matrizes/estímulos/perguntas são os dispositivos para criar uma dramaturgia não somente em um elemento cênico dado à priori, mas no que posso chamar de terreno das memórias.

\section{Videodança como escrita de si}

A noção de ter procedimentos para um novo mundo (ou o fim deste mundo atual) refletia em opções de mudanças, vontades e desejos que atravessavam todos os envolvidos no projeto. Portanto, decidi que cada vídeo seria um reflexo da minha vida em isolamento: fiz um retrospecto do período pandêmico até o momento inicial do processo criativo e a construção da coreografia se baseou, primeiramente, na noção de encarceramento.

Portanto, criei uma tessitura dramatúrgica, na qual o primeiro vídeo seria considerado uma pausa, uma volta para um silenciamento interior; o segundo, uma forma de manter o "novo normal" em atividade, criando ações, organizando agendas e retomando ao mundo; o terceiro refletiria um período quando esta nova situação não se suporta frente ao grande número de atividades ou propostas de encontro que o mundo contemporâneo proporcionou neste período (lives, reuniões, cursos), consequentes mortes e crescente número de infectados; e o quarto pretendia mostrar um ser "auto-mitológico" que se percebe Ser humano em constante evolução. Mesmo colocando uma cronologia, sei que não se pode dar a todos este caminho, pois vivemos etapas diversas nesse tempo e por isso o espectador pode direcionar uma nova rota, podendo ou não alterar essa ordem pois os acontecimentos em PFM repetem-se a ad aeternum.

Para a criação coreográfica parti inicialmente de ações cotidianas que aos poucos iam se esgarçando e se transformando em outro tipo de movimento. Esta pesquisa em torno da memória do corpo em movimento criou indicações e roteiros, trazendo uma relação com a casa, levando o corpo a jogar com o corpocasa. Uma pequena ação de mão à cabeça demonstra isso, assim como outros momentos mostrados em algumas partes do vídeo: movimentos de soltura do corpo, deixar-se cair e levantar-se, a ação do toque e consequência percepção sinestésica da pele.

A dança, segundo Rosely Conz (2013), utiliza das memórias para criação e possui um fator importante na criação, já que o "corpo é centro das investigações" (CONZ, 2013, p. 6), pois é pelo corpo que sentimos o mundo ao redor, e por ele expressamos padrões e escolhas que se presentificam nos processos criativos em dança, já que ao mesmo tempo que o bailarino move, ele é movido.

Thereza Rocha (2011) amplia horizontes quando enfatiza que o artista da dança pesquisa movimentos e busca instaurar uma anti-cena: criar a partir de movimentos investidos de caráter dialógico da sua convivência com o mundo. A autora explicita que este corpo-manifesto se aventura em metodologias que valorizam o processo e não um produto final.

É perceptível que este corpo manifesto se tornou um self mitológico. De acordo com Renato Cohen (1998) o artista na contemporaneidade, durante a construção cênica, busca por momentos numinosos, que seriam uma rasgadura do divino, um momento para que o cotidiano ganhe manifestações epifânicas. Nestes instantes instaura-se uma cena poética que, segundo Matteo Bonfitto, nasce de um treinamento baseado na poiesis, que seria "a ação de trazer algo à tona" (BONFITTO, 2009, p. 37 ), fazendo com que a obra surja numa criação que se dá de forma colaborativa: Uma cena criada em colaboração com o espaço, a casa, o corpo e seus questionamentos. Como diria Jaime Conde-Salazar (2018) no texto A dança do futuro, a dança não tem uma forma concreta, não produz obras, mas produz processos contínuos.

Para se propor um corpo poético, deve-se derivar com o processo, num constante vir a ser. $\mathrm{O}$ conceito de deriva, se anexa à ideia de Conde-Salazar (2018) e instaura aqui um olhar errante que ao mesmo tempo que estranha, se permite brincar com 
os acontecimentos. Nestes processos o artista cria espaços ficcionais próprios, que acabam desvelando um emaranhado de fios que formam a arte e vida.

Misturando genealogias e mitologias, sejam dos arquétipos do $\operatorname{Tarô}^{9}$, seja em signos gestuais que nascem no processo, pude perceber um outro ser. Com a ajuda de Bernardo Morais, diretor de fotografia, abrimos um jogo para a instauração de um corpo arquetípico, que pudesse transitar pelo processo criativo.

Pensamos nas cenas na sequência: terra, ar, água e fogo. Pensando que terra seria o lugar onde tudo está abaixo dos pés, firmeza. Porém vem o ar cheio de ideias e proposições... todos passamos por isso na quarentena, de achar que agora iremos colocar tudo em dia, otimizar o tempo, mas dá erro, vira uma ejaculação precoce. É aí que nos afogamos na água: com os medos, receios, pensamentos de como ser melhor ou pior. Por isso o vídeo foi filmado com um outro olhar de câmera, visto por cima... [referência ao ep.3 da PFM]. Será que estou no fundo do poço? Até que vem o fogo, para purgar, queimar e orientar tudo isso, mas será que vai ser completo? Será que vai conseguir agora?

Abaixo falo de cada vídeo:

Vídeo 1 Suspender / elemento- terra / Carta do tarô que escolhemos - Pendurado - procura uma terra que não sabe qual é, tem um único olhar, mas agora tem outro ponto de vista.

Carta de tarô da tiragem - Eremita - a terra se move para descobrir, para se entender, busca isolamento para encontrar calma.

Vídeo 2 Todos os caminhos / elemento $\mathrm{Ar}$ / Carta do tarô que escolhemos - Louco quer fazer pelo impulso. Foda-se, quero fazer. Nada o prende, segue o fluxo e cria o fluxo.

Carta de tarô da tiragem - Imperatriz - sei fazer qualquer coisa, quero construir, mas caí porque sou jovem e preciso de experiência.

9 Houve um momento do processo criativo em que Bernardo Morais e eu, estudamos arquétipos do Tarô em busca de atmosferas cênicas. Escolhemos uma carta arquetípica para cada momento vivido pela ser auto mitológico, e a seguir realizamos uma tiragem de tarô para indicar um superobjetivo de cena. Então a primeira carta foi escolhida, tendo por base um elemento (terra, ar, água e fogo), e a segunda foi tirada do jogo, como um conselho para o personagem.
Vídeo 3 Delírio / Elemento Água / Carta do tarô que escolhemos - Lua - Emergir nas profundezas dos medos e das ilusões, tentar encontrar um horizonte. Acabou, então agora que vai começar.

Carta de tarô da tiragem - Julgamento - Intuição. Anúncio para uma nova fase. Chamada para o novo. Caixões flutuando na água. Vídeo 4 Gênius / Elemento fogo / Gênius é um deus grego do nascimento. Cada pessoa tem o seu genius, ele é o elemento infantil de poder e de que tudo pode. Ele é um momento de pura alegria e presença. As festas antigas para este deus se desdobraram no que chamamos hoje de festas de aniversário. Espaço para celebrar a presença, o momento. Carta do tarô que escolhemos - Roda da fortuna - ilumina para todos os caminhos. É um momento de parada para um novo passo. Abertura para o que vem.

Carta de tarô da tiragem - Sol - Êxtase completo. Plenitude e sagacidade (trecho de conversa em WhatsApp com o compositor).

A busca por um mito pessoal se presentifica quando crio coreografia a partir do inconsciente, dando à materialidade imagens internas que, quando editadas e finalizadas em vídeo, criam signos indicadores de atitudes, posições ou situações gerando sensações diversas no espectador.

Nasce assim um ser auto-mitológico, que ressoa no corpo e no espaço, tornando o corpo um outro-estranho. O álter ego mitológico ganha espaço livre entre a vida e a arte, libertam-se para retomar fatos dessa memória e ressignificá-las em outras rotinas diárias e cotidianos íntimos para que a obra ganhe uma dimensão intermediária entre o eu-artista e o eu-personagem.

Estas práticas artísticas que levam a estas indagações, para Foucault (1992; 2004) são "práticas do eu", momentos de consciência de si e do mundo ao redor. Desta forma posso evidenciar a presença de um ser que não sou eu e muito menos um personagem. Cria-se então um álter ego de quem escreve/dança que tenta em movimentos encontrar estes sentimentos que são pertinentes a todos.

$\mathrm{Na}$ autobiografia isto se expressa quando o artista se mitifica para expor-se, ou se autoproclama dono da história, portanto é a pessoa mais indicada para tecer pormenores. "Em resumo, estes artistas expandem a nossa compreensão sobre aquilo que significa estar vivo hoje. Eles usam a arte para mostrar os modos complexos com que criamos histórias 
sobre nós próprios" (GUERREIRO, 2011, p. 129).

Durante a produção de PFM, eu instauro um espaço para o encontro, e pude perceber que a solidão de que estes procedimentos falam, são as minhas pequenas solidões cotidianas. Para clarificar isso, pensei em uma pequena sinopse que pretende orientar o espectador a uma possível apreciação estética.

Daqui, deste lugar, vejo os corações sob o muro. Isolado, tento me entregar ao vazio de dentro enquanto o vazio de fora está repleto de repetições miúdas de mim mesmo. Daqui, deste lugar, vejo os muros cada vez mais altos. Um sinal de adeus me leva de frente a mim mesmo, me olho nos espelhos da atualidade enquanto passa o tempo lá fora. Os caminhos se abrem enquanto uma sensação de tempo perdido me consome. Não há caminhos e, ao mesmo tempo, tenho todos presos nas palmas da minha mão (sinopse PFM, Ep. 2. Todos os caminhos, 2020).

O lugar autobiográfico abre caminhos para que o artista manipule, finja, crie e profane imagens, desenhos, diários. Podendo assim, criar um autorretrato ficcional, onde eu e o outro se deparam e, vez ou outra, este outro é o espectador, mas de todas as vezes quem nos encara é a mitologia própria que se forma, unindo seres e espaço.

\section{Uma anti-cena na ante-sala}

Com estreia em outubro de 2020 , e com processo de montagem curto, o projeto me levou a transformar uma área de convívio de casa em espaço de ensaio, onde eu me aquecia com prática de Ashtanga Yoga e me abria para uma escuta sensível do movimento pesquisado nessa tessitura corporal. Os espaços da casa servem agora para perceber o meu corpo em isolamento, buscando em minha memória recente atravessamentos e sintomas do isolamento social.

Os ensaios ocorreram em dias alternados e seguiram geralmente a ordem comum de ensaios de dança nos quais, materiais foram filmados para acrescentar ao registro a ideia de diário de artista, e eram constantemente revisitados, pelo diretor de fotografia, a fim de encontrar novas possibilidades de ligação entre corpo, cena e câmera.

Como a minha proposta era ser recolhido pelo movimento, diversas vezes me via em alguma parte da casa, confabulando sobre o processo e, destes momentos, apareciam células de movimento.

Um item interessante para o processo foi o material escolhido para compor os espaços: as folhas secas recolhidas nos arredores da casa são utilizadas para remeter à uma noção de fragilidade e singularidade.

\begin{abstract}
Porque todas as pessoas projetam uma imagem particular de si próprias, mas raramente esta imagem coincide ou está de acordo com as percepções dos outros. Toda a gente carrega memórias do passado, mas geralmente elas são distorções selectivas da verdade. Toda a gente tem uma história de vida para contar, mas normalmente ela é mais próxima da ficção do que da realidade (GUERREIRO, 2011, p. 125)
\end{abstract}

Portanto este trabalho estabelece movimentos que surgem de uma pesquisa de memória cinestésica, em um tipo de pesquisa corpórea na qual o corpo pretende ser recolhido pelo movimento, relacionando memórias, sensações e desejos, procurando sensorialidades que se apoiem em escombros e escuros. PFM relaciona memória e corpo, usando o movimento para inventar-se, criando um mundo onde álter egos mitológicos podem realizar pedaços de sonhos frustrados.

\section{Conclusão}

Proporcionar um trabalho de dança que pretende ser exposto por vias alternativas não presenciais reflete a necessidade de se pensar a produção de imagens hoje, especialmente imagens que tenham o corpo como centro do discurso, este corpo torna-se um elemento importante no mercado cultural, seja um corpo dançante ou não.

Num trabalho que visa refletir sobre a relação do próprio intérprete sobre a solidão deixada pela pandemia de 2020/2021 e entender a força do lugar onde mora como um reflexo de si, dá a este trabalho um cunho autobiográfico visto que, para Bachelard, a força representada da casa é corpo e alma, e também o primeiro mundo do ser humano. O trabalho de alguma forma expõe este estranhamento que todos nós passamos durante o confinamento do ano de 2020, no qual fomos forçados a olhar e encarar este reflexo de forças, reencontrando-nos nos primórdios da nossa própria constituição.

Pensar nos lugares que ocupamos e na impos- 
sibilidade de ocupá-los atualmente, faz da casa o lugar de aconchego de berço e formação, mas também um lugar de extremo incômodo onde eu, enquanto artista, fui confrontado. A noção de pausa e necessidade de reconstrução do ser, mostram-se no movimento de fechar as janelas, e no encontro com o espaço de dentro, um confronto que, segundo Michael Foucault é um lugar de convergência com fantasmas, pois é neste espaço que a nossa percepção íntima e nossos devaneios. Este lugar onde o passado, presente e futuro se encontram em um espaço sem tempo, reflete na dramaturgia sem final, em moto perpétuo. Nota-se que ao final, o corpo gira e clama por algo, espiralando-se enquanto procura um novo foco, no espaço trancado da casa, num ato de confronto e exposição.

O processo de criação durante a quarentena e em casa foi um processo complexo e promovia constantes adaptações seja na questão de movimento quanto na proposição de amplitude de movimentos. O trabalho ganhou ares de uma dança minimalista que mesmo não aparentando, se relacionada a um virtuosismo do corpo. Acredito que esta característica se deu pela noção de "corpocasa" como abertura para as experiências de fragilidade que vivi nesta época. Uma dança intimista, baseada num cotidiano de isolamento, que me faz adentrar em lugares empoeirados, mas que, ao serem descobertos, abrem espaço para uma cosmovisão diferenciada da vida enquanto artista. Um movimento que nasce para amparar o espaço e vice versa, em uma dança que é expressão de aspectos que não existiam em mim, ou que não os conseguia identificar. Estes escombros do corpocasa descobrem-se enquanto porta para uma performance artística que é uma reelaboração da própria vida, com seus anseios e defeitos.

No primeiro capítulo do "Poética do espaço", intitulado "A casa. Do porão ao sótão. O sentido da cabana", Bachelard trata a casa como "um verdadeiro cosmos" (2000, p. 24). Este lugar de criação é o lugar primordial do homem, e o acolhe e o propícia ao sonho, onde pode também desfrutar da solidão, é esta solidão que faz o indivíduo confrontar as paredes da casa percebendo-a como um lugar de estabilidade. É a casa que "deve guardar sua penumbra" (BACHELARD, 2000, p. 32), pois é através deste lusco-fusco, de suas sombras, que se cria imagens.

Em uma videodança onde apresenta-se um indivíduo enclausurado, pode-se pensar: Que casa é esta? A casa natal que gera no ser a noção de habitação? Seria uma casa que este personagem passou a sua vida inteira? Ou um apartamento recém alugado? Estaria ele deixando esta casa, se dirigindo para outra?

Estas penumbras deixam partes cobertas, como as folhas que recobrem o piso e uma mesa, que dão a casa um lugar para um devaneio verticalizado que caminha para os lugares mais altos da casa, saindo do lugar de escuros e receios e encaminhando-se para o telhado, claro, oxigenado. No entanto, neste devaneio centralizado percebe-se uma casa mais simples, aconchegante e que mostra lembranças letárgicas, depositadas no conforto da intimidade do sujeito. Pode-se ver claramente este conceito no terceiro vídeo da série, quando o personagem se entrega à solidão no "centro de um devaneio" (BACHELARD, 2000, p. 56).

Percebi que a casa mostrada nos vídeos, não é mais somente minha, mas se reflete ao momento que o espectador está atravessando: caso o enfrentamento pandêmico esteja mais tranquilo, a casa se torna um lugar de morada natal, aconchegante e entregue ao devaneio, porém se o espectador está de alguma forma percebendo-se inseguro, seja por deslocamentos constantes, ou enfrentamentos mais diretos com o vírus, esta casa se torna concreta e triste, afastando-o assim do devaneio.

Bachelard apresenta uma "ritmanálise da função de habitar" $(2000$, p. 78$)$ onde o sonhador professa a intimidade do mundo, porém só há este aprendizado quando existe reflexão sobre a casa. Entendo aqui que o autor propõe um momento de encontrar-se dentro de casa, no corpocasa, uma meditação sobre os pequenos atos e pequenos ritmos, ação necessária nestes tempos pandêmi$\cos$. Ao visualizar o resultado final percebo que, no processo da escolha dos movimentos, da estética de figurino e do modo de captação de imagens, fez-me perceber um lugar de intimidade e fragilidade, questões que estamos todos enfrentando neste período.

\section{Referências}

BACHELARD, Gaston. A poética do espaço. São Paulo: Martins Fontes, 2000.

BARBA, Eugenio. Dramaturgia. In: BARBA, Eugenio, SAVARESE, Nicola. A arte secreta do ator: dicionário de antropologia teatral. Tradução de L. O. Burnier et al. São Paulo-Campinas: Hucitec - Unicamp, 1995. 
BONFITTO, Matteo. Tecendo os sentidos: a dramaturgia como textura. Pitágoras 500, Campinas, SP, v. 1, n. 1, p. 56-61, 2011. DOI: 10.20396/ pita.v111.8634753. Disponível em: https://periodicos.sbu.unicamp.br/ojs/index.php/pit500/article/ view/8634753. Acesso em: 18 abr. 2021.

CONDE-SALAZAR, Jaime. La danza del futuro. Madrid: Continta me tienes Editorial, 2018.

COHEN, Renato. Work in progress na cena contemporânea. São Paulo: Perspectiva, 1998.

CONZ, Rosely. Resquícios e rosas: as memórias na criação em dança contemporânea, p. 1412013. Dissertação (Mestrado) - Universidade Estadual de Campinas, Instituto de Artes, Campinas, SP. Disponível em: http://www.repositorio.unicamp.br/ handle/REPOSIP/284527. Acesso em: 23 nov.2020.

FOUCAULT, Michel. A escrita de si. In: O que é um autor? Lisboa: Passagens. pp. 129-160. 1992.

. A ética do cuidado de si como prática da liberdade. In: Ética, sexualidade e política, por Michel FOUCAULT, 264-287. Rio de Janeiro: Forense Universitária, 2004.

GUERREIRO, Nelson: Estás onde? Reflexões sobre autobiografia e autoficção nas práticas artísticas contemporâneas. In: Cadernos PAR n. ${ }^{\circ}$ 4 (Mar. 2011), p. 125-138. Disponível em: https://iconline.ipleiria.pt/bitstream/10400.8/407/1/ Par4_art10.pdf. Acessado em: 01 nov. de 2020.

DEBORD, Guy-Ernest. Teoria da deriva. In: JACQUES, Paola Berenstein (Org.). Apologia da Deriva: escritos situazionistas sobre a cidade. Rio de Janeiro: Casa da Palavra, 2003. [Publicado originalmente em Internacionale Situationniste, n. 2, 1958].

KLINGER, Diana. Escrita de si como performance. Revista Brasileira de Literatura Comparada, n. 12, p. 11-30, 2008.

LYRA, Luciana de Fátima Rocha Pereira de. Mito Rasgado - Performance e Cavalo Marinho na cena In processo. Dissertação (Mestrado) - Universidade Estadual de Campinas. Instituto de Artes. Campi-
nas/SP. 2005.

PAIS, Ana. O crime não compensa ou o poder da dramaturgia. Sigrid Nora (Org.) In: Temas para a dança brasileira. São Paulo: Edições SESC/SP, p. 344, 2010.

ROCHA, Thereza. O que é dança contemporânea? A Narrativa de uma impossibilidade. Revista ENSAIO GERAL, Belém, v. 3, n. 5, jan./jul., 2011. SANCHEZ, Lícia Maria Morais. O Processo Pina-Bauschiano como Provocação à Dramaturgia da Memória. 212f. (Mestrado em Artes) - Instituto de Artes, Universidade Estadual de Campinas, Campinas/SP, 2001.

Recebido: 24/04/2021

Aceito: 15/10/2021

Aprovado para publicação: 08/11/2021

Este é um artigo de acesso aberto distribuído sob os termos de uma Licença Creative Commons Atribuição 4.0 Internacional. Disponível em: http://creativecommons.org/licenses/by/4.0.

This is an open-access article distributed under the terms of the Creative Commons Attribution License 4.0 International. Available at: http://creativecommons.org/licenses/by/4.0.

Ce texte en libre accès est placé sous licence Creative Commons Attribution 4.0 International. Disponible sur: http://creativecommons.org/licenses/by/4.0. 